\title{
Histórias do inconsciente antes de Freud
}

\author{
Nelson Ernesto Coelho Junior
}

\begin{abstract}
Magnetismo animal e cenestesia: temas centrais da história do inconsciente? Abade Faria, Puységur, Ribot, Briquet, Azam, Thouret, Mesmer, Deslon e Braid: autores representativos da história do inconsciente? Que história é essa?

Essa é a história ou, como podem preferir os mais freudianos, a pré-história do inconsciente, em um de seus capítulos mais fecundos e significativos, aquele da constituição do conceito e da experiência do inconsciente nas práticas clínicas da França do século XIX. História que é o tema do instigante livro do professor (PUC-SP e Instituto Sedes Sapientiae) e pesquisador Sidnei José Cazeto, que se situa assim, a seu modo, na tradição formada pelas obras de Henri Ellenberger, autor do magistral A história da descoberta do inconsciente (1970) e Lancelot Whyte, autor de $O$ inconsciente antes de Freud (1960). O leitor encontrará neste livro o resultado de vários anos de uma rigorosa pesquisa bibliográfica, realizada em grande parte na antiga Biblioteca Nacional em Paris, onde se encontram exemplares únicos de muitos dos livros que constituem este fundamental período de construção de nosso conhecimento sobre o mundo anímico. Sem negar sua origem acadêmica (o livro é a publicação de uma tese de doutorado defendida pelo autor, em 2000, no Programa de Estudos Pós-Graduados em Psicologia
\end{abstract}


Clínica da PUC-SP), o texto revela um inventivo estilo de reconstrução de muitas das histórias da constituição do que hoje chamamos, de boca cheia, o inconsciente.

Ao seguir as trilhas propostas pelo professor Cazeto, o leitor acabará por reconhecer que o conceito estudado (de um inconsciente psíquico) não é algo pré-definido, mas sim "uma composição laboriosa de esforços de investigação, acasos, descobertas e invenções com o material disponível a cada momento” (p. 346). Mas, como nos lembra o autor, o mesmo vale para o passado rastreado, já que este "também 'não estava lá', à espera de nossa procura, em que pese a documentação existente, conservada em bibliotecas, a oferecer este tipo de imagem.” (p.346) E aqui encontra-se um dos grandes méritos deste livro, ou seja, a capacidade do autor em "animar seus personagens", fazendo uma história viva, sem transformar fatos e relatos em letra morta, mas ao mesmo tempo mantendose na tradição mais rigorosa e precisa das melhores pesquisas históricas no campo das Ciências Humanas.

O professor Cazeto, ao destacar os trabalhos dos médicos, pesquisadores e, por que não, também dos charlatões franceses do século XIX, acaba estabelecendo um percurso que vai da crença na dimensão "material-corporal" (físico-química-fisiológica), do assim chamado inconsciente, à crença no inconsciente propriamente psíquico, em termos de representações psíquicas. Mas ficará claro, ao leitor atento, que o autor não nos apresenta este percurso como estando concluído, ao se alcançar o ponto de chegada das representações psíquicas. Há algo que insiste e persiste na tensão entre as dimensões "materialcorporal” e "psíquico-representacional”, e isso precisa ser tomado em seu aspecto positivo. Na psicanálise contemporânea, não por acaso, retoma-se com toda força o debate sobre o "lugar" dos afetos, assim como sobre os diferentes planos de relação entre o corporal e o anímico e também sobre os aspectos nãorepresentacionais que constituem o psiquismo.

O livro estrutura-se a partir do estabelecimento de algumas oposições fundamentais para esta refinada elaboração de um dos capítulos iniciais da história do inconsciente. São elas: a oposição entre "uma consciência” e "consciência dupla ou dividida”; a oposição já citada entre “a esfera fisiológica (material)” e “a esfera das idéias (representações)” e, por fim, a oposição entre "o inconsciente na patologia” e “o inconsciente na saúde”. Diante destas oposições, e acompanhando a solução estabelecida pela psicanálise, o autor acaba por afirmar, perto de sua conclusão, que "no que se refere ao inconsciente, este novo modelo [a psicanálise] será pleno de conseqüências, pois agora fica possível falar em representações inconscientes segundo uma dinâmica de forças que torne prescindível transferir a discussão para o plano cerebral, e dispensável a idéia de uma segunda consciência” (p. 338). Não resta dúvida que as postulações freudianas representaram uma grande revolução na história da constituição e do 
conceito de inconsciente. Mas, ao mesmo tempo, a noção de representações inconscientes pode iludir em seu poder de aparentemente tudo solucionar, no que diz respeito ao estatuto teórico do inconsciente. Em termos psicanalíticos, a oposição entre afeto e representação continua a gerar impasses que, de resto, são fundamentais para o desenvolvimento do conhecimento em nossa área. Além disso, não custa relembrar, têm sido grandes os esforços atuais para colocar lado a lado pesquisadores oriundos da psicanálise com neurologistas e bioquímicos, procurando avançar nos estudos que envolvem tanto a esfera fisiológica como a cognitiva/representacional do psiquismo. Com isso, não penso que precisem ser revistos os postulados da psicanálise, nem a especificidade de seus conceitos e teorias. Postulo, apenas, que a concepção do inconsciente como constituído fundamentalmente pelo plano das representações inconscientes talvez não seja o ponto de chegada desta fascinante história do inconsciente.

A pesquisa do professor Cazeto provocará, também, saudáveis efeitos nostálgicos no leitor. Nostalgia da época em que a maior parte da energia despendida por pesquisadores da área "psi” era dirigida para um incansável trabalho "corpo a corpo" com os enigmas colocados por pacientes, pelo enigma representado por suas doenças. Será que o peso quase hegemônico de teorias mais ou menos explicativas, protegidas pelo arsenal de grandes instituições e associações da área, de um lado, e medicamentos "milagrosos" da grande indústria farmacêutica multinacional, de outro, nos fez ficar imunes diante de muitos enigmas clínicos que de alguma forma persistem? Os exemplos relatados pelo professor Cazeto são revigorantes e nos relembram que saber valorizar enigmas clínicos é fonte inigualável de produção de conhecimento em nossa área. E, além disso, como nos lembra Luís Claudio Figueiredo em sua apresentação do livro, "é bom poder rir um pouco da ciência deles, já nos preparando, enquanto é tempo, para rir de nossa própria” (p.11).

Essas duas capacidades fundamentais, perplexidade diante de enigmas clínicos e capacidade de rir de sua própria ciência, estão, infelizmente, em grande desuso no campo das pesquisas e publicações em psicanálise, psicopatologia e psiquiatria. Este livro do professor Cazeto, seu exemplo como pesquisador, assim como as divertidas, curiosas e sérias histórias dos personagens e de suas aventuras nas práticas clínicas na França do século XIX, apresentam as melhores condições para ativar no leitor o uso destas esquecidas capacidades. 